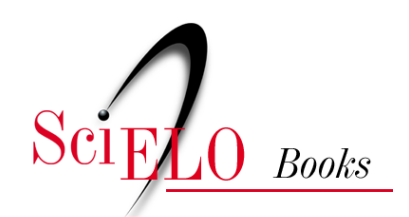

Editora da UESC

\title{
Biografemas homoculturais de Eva Perón no romance Santa Evita, de Tomás Eloy Martínez
}

\author{
André Luis Mitidieri
}

\section{SciELO Books / SciELO Livros / SciELO Libros}

MITIDIERI, AL. Biografemas homoculturais de Eva Perón no romance Santa Evita, de Tomás Eloy Martínez. In: MITIDIERI, AL., and CAMARGO, FP., orgs. Literatura, homoerotismo e expressões homoculturais [online]. Ilhéus, BA: Editus, 2015, pp. 41-75. ISBN 978-85-7455-442-6. Available from SciELO Books <http://books.scielo.org>.

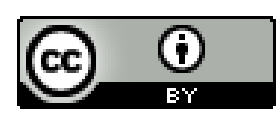

All the contents of this work, except where otherwise noted, is licensed under a Creative Commons Attribution 4.0 International license.

Todo o conteúdo deste trabalho, exceto quando houver ressalva, é publicado sob a licença Creative Commons Atribição 4.0.

Todo el contenido de esta obra, excepto donde se indique lo contrario, está bajo licencia de la licencia Creative Commons Reconocimento 4.0. 


\title{
BIOGRAFEMAS HOMOCULTURAIS DE EVA PERÓN NO ROMANCE SANTA EVITA, DE TOMÁS ELOY MARTÍNEZ
}

\author{
André Luis Mitidieri ${ }^{1}$
}

O modo como o sujeito-autor se posiciona no discurso da crítica contemporânea pode variar: alguns adotam uma posição de distanciamento e outros se entrelaçam ao corpus escolhido, acompanhando o movimento de entrada e saída do gesto enunciativo. Viabilizam-se olhares diferenciados a gêneros menores, a uma tradição literária desviada do foco das grandes narrativas, processados através das margens e dos bastidores. Os centros acadêmicos não mais definem os critérios de preferência e valores estéticos, ao mesmo tempo em que momento atual apresenta critérios híbridos e mais abrangentes: "os cânones e a tradição literária atuam sorrateiramente sobre a experiência singular do fazer artístico, atividade secular que se nutre de revivals e revisitações" (SOUZA, 2002, p. 90).

1 Mestre e doutor em Letras, área de concentração em Teoria da Literatura, pela PUCRS. Professor Titular no Curso de Letras da Universidade Estadual de Santa Cruz (UESC). Docente de Literatura e História no Programa de Pós-Graduação em Letras - Mestrado em Linguagens e Representações (UESC). E-mail: 〈almpereira@uesc.br>. 
Ao mesmo tempo, a proliferação de práticas discursivas tidas como extrínsecas à literatura, a exemplo da

\begin{abstract}
[...] cultura de massa, as biografias, os acontecimentos do cotidiano, além da imposição de leis regidas pelo mercado, representam uma das marcas do nosso tempo, que traz para o interior da discussão atual, a democratização dos discursos (SOUZA, 2002, p. 90).
\end{abstract}

Nesse conjunto, e após longo expurgo por boa parte do século XX, a abordagem biográfica retorna aos estudos históricos, porém, não mais voltada às ações dos "grandes vultos da história", muito menos por intermédio da mera inserção de personalidades desse tipo em seus respectivos contextos, mas buscando analisar os principais eventos nos quais poderia estar envolvida.

De outro modo, os estudos histórico-biográficos contemporâneos têm em mente as relações entre acontecimentos, conjunturas e estruturas, elites e massas, individuos e grupos, palavra e ação. É pensando também na reestruturação do próprio gênero biográfico, de suas formas e de seus meios de viabilização nos estudos históricos, que François Dosse (2007) escreve La apuesta biográfica: escribir una vida. Nesse livro, o historiador destaca o conceito de "biografema", estabelecido pelo teórico homossexual Roland Barthes (1971, p. 12), quando aborda as representações pela linguagem através de um conceito tributário da noção de fonema: 
Se eu fosse um escritor, já morto, como gostaria que minha vida se reduzisse, pelos cuidados de um biógrafo amigo e desenvolto, a alguns pormenores, a alguns gostos, a algumas inflexões, digamos: 'biografemas', cuja distinção e mobilidade poderiam viajar fora de qualquer destino e vir tocar, à maneira dos átomos epicurianos, algum corpo futuro, prometido à mesma dispersão; uma vida furada, em suma, como Proust soube escrever a sua na sua obra, ou então um filme à moda antiga, de que está ausente toda palavra e cuja vaga de imagens (esse flumen orationis em que talvez consista 'o lado porco' da escritura é) entrecortada, à moda de soluços salutares, pelo negro apenas escrito do interstício, a irrupção desenvolta de outro significante: o regalo branco de Sade, os vasos de flores de Fourier, os olhos espanhóis de Inácio.

Vidas vividas juntam-se a sinais diversos, imagens, resíduos sígnicos, também indagando sobre a realidade, nos corpúsculos biografemáticos que Barthes (1990, p. 11) detecta em Fourier: "seu gosto pelos 'mirlitons' (bolinhos parisienses com aromatizantes), sua simpatia tardia pelas lésbicas, sua morte entre os vasos de flores". Essas formas residuais, esses cacos particulares da existência, depõem acerca do sujeito de uma forma singular:

[...] o que me vem de Loyola não são as peregrinações, as visões, as macerações e as constituições do santo, mas 
somente os seus belos olhos, sempre um pouco marejados de lágrimas. Porque, se é necessário que, por uma retórica arrevesada, haja no Texto, destruidor de todo sujeito, um sujeito para se amar, tal sujeito é disperso, um pouco como as cinzas que se atiram ao vento após a morte (ao tema da urna e da estela, objetos fortes, fechados, instituidores de destino, opor-se-iam os cavacos de lembrança, a erosão que só deixa da visa passada alguns vincos) (BARTHES, 1990, p. 12).

Tais vestígios permitem refigurar as muitas histórias que poderiam ter ocorrido, e não somente a história estabelecida. Operações metonímicas, como as que se viabilizam por intermédio do conceito de biografema, somam-se às considerações atuais quanto a uma historiografia da literatura que se nega à canonicidade fixa ou presa a um só contexto. Daí a presente atenção aos lugares móveis dos textos e a seus sentidos, em lugar dos enquadramentos unânimes, nacionais, lineares, uniculturais.

É assim que buscamos articular a ideia barthesiana de biografema à crítica cultural contemporânea, a fim de desenvolvermos a noção de "biografema homocultural", a partir do romance Santa Evita ${ }^{2}$, de Tomás Eloy Martínez, num momento em que o contexto his-

\footnotetext{
2 MARTÍnEZ, Tomás Eloy. Santa Evita. São Paulo: Companhia das Letras, 2006. Todas as citações do romance, aqui utilizadas, foram retiradas desta edição, e identificadas pelos respectivos números das páginas.
} 
tórico e suas interpretações auxiliam a compreender tudo aquilo que, à primeira vista, pode parecer inexplicável ou desconcertante. Lidando com modelos divergentes, podemos nos associar à reflexão sobre as diferenças entre um espelho (no singular) e os espelhos (no plural); quer se disponham "um em face do outro (imagem zen), de maneira a refletirem sempre o vazio, quer a multiplicidade dos espelhos justapostos cerque o sujeito com uma imagem circular cujo vaivém fica por isso mesmo abolido" (BARTHES, 1990, p. 129).

François Dosse (2007) menciona o tensionamento vivido por Roland Barthes, em 1971, quando escreve Sade, Fourier, Loyola, entre o rigor da teoria estruturalista e os prazeres da escritura mais liberta de técnicas rigidamente definidas. Nesse texto, como visto, Barthes constrói os sujeitos do enunciado, a partir de pequenos detalhes que muito revelam sobre as personalidades históricas; afastando-as da unicidade, faz jus às múltiplas posições que elas ocuparam no universo social, além de inovar na narração de vidas.

O uso de pormenores mais significativos rompe com a tradicional linearidade do gênero biográfico, oferecendo perspectivas parciais dos indivíduos, mas aptas a compor uma visão da pluralidade humana. Assim, o caráter não linear do biografema se fundamenta na mobilidade e na fluidez, oferecendo sinais entrecortados que proporcionam a materialização ou as interpretações da multiplicidade do indivíduo e das sociedades. A 
ideia de uma escrita biográfica menos maciça e mais indicial, portanto aproximada a então recente micro-história italiana (de Carlo Ginzburg, Giovanni Levi e Simona Cerutti, dentre outros), ganha destaque no sistema de pensamento do estudioso francês e nos estudos (auto)biográficos que, após longo ostracismo, voltam à cena teórica francesa, em meados dos anos 1970.

Tamanha importância adquire a noção barthesiana nesse contexto, de onde migra com sucesso para os centros universitários ocidentais, que retorna, em livro publicado originalmente no ano de 1980, Câmara clara (BARTHES, 1984, p. 153), estritamente vinculada com aquele instante ímpar de um sujeito, captado pela fotografia, quando,

[...] às vezes, faz aparecer o que ja-
mais percebemos de um rosto real (ou
refletido em um espelho): um traço
genético, o pedaço de si mesmo ou de
um parente que vem de um ascen-
dente. Em tal foto, tenho o 'focinho'
da irmã de meu pai. A Fotografia dá
um pouco de verdade, com a condição
de retalhar o corpo. Mas essa verdade
não é a do indivíduo, que permanece
irredutivel; é a da linguagem.

Para definir um dos vastos elementos capazes de explicar o interesse despertado por fotografias que, portadoras de um afeto médio, se fazem perceber com familiaridade devido à cultura moral e política ou ao saber do observador, mas sempre enviam a 
uma informação clássica, Barthes (1984, p. 45) utiliza-se do termo latino studium, "que não quer dizer, pelo menos de imediato, 'estudo', mas a aplicação a uma coisa, o gosto por alguém, uma espécie de investimento geral, ardoroso, é verdade, mas sem acuidade particular". O segundo elemento, por sua vez, parte da cena, à maneira de uma flecha; nomeado como punctum, "é também picada, pequeno buraco, pequena mancha, pequeno corte - e também lance de dados. O punctum de uma foto é esse acaso que, nela, me punge (mas também me mortifica, me fere)" (BARTHES, 1984, p. 46).

Em contraste com o studium, o punctum expressa a "zebrura inesperada que às vezes vinha atravessar esse campo" (BARTHES, 1984, p. 141) e, ao se desprender do detalhe, não sendo mais uma questão "de forma, mas de intensidade, é o Tempo, é a ênfase dilaceradora do noema ('isso foi'), sua representação pura" (BARTHES, 1984, p. 141). Tanto num quanto em outro caso, o punctum se associa intimamente ao biografema, conceito que há tempos integra o repertório e o vocabulário da teoria literária contemporânea, permitindo a reconstituição das formas e dos gêneros do espaço biográfico por intermédio da recorrência à imagem fragmentária do sujeito, cuja totalidade da vida é completamente impossivel de ser atingida por uma construção narrativa.

Desse modo, a escrita biografemática abrese à interpretação dos leitores que, por sua vez, refazem a imagem dos sujeitos biografados, a partir de associações fundadas em momentos 
de vida entrecruzados a outras existências e a outras avaliações. Como esta, outras formas de escrita biográfica não eliminam a hipótese de o sujeito produtor do discurso recorrer à imaginação para, inclusive, preencher vazios sobre acontecimentos aos quais não pôde ter acesso, mediado por documentos, fontes, rastros. No entanto, o jogo entre os elementos verídicos e a ficção irrecusável pode se restringir devido ao pacto (auto)biográfico, que, envolvendo autor e público leitor/receptor, parece reger as formas e os gêneros integrantes do "espaço biográfico", assim denominado por Leonor Arfuch (2010).

Devido principalmente às possibilidades que apresenta de proceder a desvios, em relação ao cânone literário e às hierarquizações da história oficial, é que a noção de biografema se conjuga à "homocultura" enquanto lócus de estudo e representação de expressões culturais, produzidas por sujeitos homossexuais e/ ou a seu respeito, bem como das visões e dos diálogos que proporcionam, a partir da ruptura com os discursos hegemônicos e da crítica às heteronormatividades.

Nesse âmbito, representações biográficas, históricas e literárias de Eva Perón, elaboradas por Juan José Sebreli (1966), Manuel Puig (1966), Osvaldo Lamborghini (1969) e Raúl Natalio Roque Damonte Botana Taborda, o Copi (1970), inovavam ao mostrar as ambivalências do fetiche, evocado pelo nome de Eva e pela face camp da atriz a se desempenhar nos palcos do poder. Entre a "guerra suja" (1976-1983) que marcou a era ditatorial na Argentina e a futura 
redemocratização do país, outros acréscimos a sua imagem; alguns que satisfazem a curiosidades privadas; outros que mais ainda a deslocam das margens da sociedade militarizada e patriarcal sobressaem nos textos de autoria homossexual dedicados à "Dama da Esperança", por seu costureiro Paco Jaumandreu (1975; 1981), pela poetisa María Elena Walsh (1976) e pelo escritor Néstor Perlongher (1975, 1980, 1983, 1989).

David William Foster (1999, p. 529) ressalta, dentre as várias configurações assumidas pelo ícone de Evita, no imaginário social do Rio da Prata, a sua identificação como figura de proa para a cena LGBT no período pósditatorial:

'Si Evita viviera, seria tortillera'. Con este tropo, tomado del grito de combate del movimiento guerrillero de la izquierda argentina, 'Si Evita viviera, sería montonera', el naciente movimiento gay de los ochenta (el cual fue posible solamente gracias a la redemocratización de la post-dictadura y la determinación de Argentina de ser absolutamente moderna) intentó reclamar a Eva Duarte de Perón como un potente simbolo ${ }^{3}$.

3 "'Se Evita vivesse, seria sapatão'. Com esse tropo, tomado de empréstimo do grito de combate do movimento guerrilheiro da esquerda argentina, 'Se Evita vivesse, seria montonera', o nascente movimento gay dos anos 1980 (que se fez possível graças somente à redemocratização da pós-ditadura e à determinação da Argentina a ser absolutamente moderna) tentou reclamar Eva Duarte de Perón como um potente símbolo” (FOSTER, 1999, p. 529 - tradução nossa). 
O desvelamento da mulher como um "ícone da inscrição da Argentina no texto da modernidade periférica", paralela a sua atuação, fosse primeiramente como atriz, fosse mais tarde como liderança politica que usou e abusou dos meios de comunicação de massa, principalmente do rádio, entrelaça-se a uma experiência coletiva, conforme lembra Susana Rosano (2005, p. 274-275). Do corpo que jogou papel fundamental na entrada do peronismo em cena e na inscrição do populismo platino junto ao imaginário modernizador nacional, o tropo de Eva Perón:

[...] se articula a una serie de indagaciones experimentales que eligen interrogar al personaje desde una pregunta desestabilizadora: su condición de mujer. Desde alli surgen reinvenciones que paradójicamente convierten a este icono del nacionalismo en una figura marginal de tintes posmodernos. El performance de Evita se reviste asi con los colores estridentes de la estética camp y de alli surgen imágenes sorprendentes de una Eva travesti, lumpen, fiestera, absolutamente marginal a las sintaxis explicativas que previamente habian articulado los discursos tanto de la ortodoxia peronista como de la oposición liberal ${ }^{4}$.

\footnotetext{
4 "[...] articula-se a uma série de indagações experimentais que optam por interrogar a personagem desde uma pergunta desestabilizadora: sua condição de mulher. Desde então surgem reinvenções que paradoxalmente convertem esse ícone do nacionalismo em uma figura marginal de matizes pós-modernos. A performance de Evita reveste-se assim com as cores estridentes da estética camp e daí surgem imagens surpreendentes de uma Eva
} 
Levando isso em conta, a ideia de "biografema homocultural" permite-nos analisar a tradução brasileira do romance de Tomás Eloy Martínez, intitulado Santa Evita (1996). Assim, em uma das várias inserções metatextuais a que procede, o autor nos informa que, em Eva Perón, drama de Copi encenado pela primeira vez em Paris, no ano de 1970, "Evita mostrava a bunda. Na peça ela oferece seu amor como pode ou como sabe" (p. 173). Entretanto, trata-se de um poder amputado e de um saber controlado, pois o dramaturgo elide os materiais da Evita revolucionária, trazendo para seu lugar o julgamento e a desqualificação, promovidos pelos antiperonistas da década de 1950, segundo Beatriz Sarlo (2005, p. 237).

Caso tomássemos a frase de Martínez ao pé da letra, as possibilidades e os conhecimentos amorosos de Eva, no referido drama, se restringiriam ao seu derriére. A lembrança do passado da protagonista "não serve de base para um sentimentalismo generoso, e sim para um conhecimento desencantado e cínico da vida" (SARLO, 2005, p. 19). Sem negar a classe média antiperonista, de onde provém, e para a qual a mulher de Perón era nada mais do que a intrusa, a prostituta, a ressentida, Copi

[...] trabalharia com esses discursos da infância e, naturalmente, imprime a

travesti, lumpemproletária, festeira, absolutamente marginal às sintaxes explicativas que previamente haviam articulado os discursos tanto da ortodoxia peronista como da oposição liberal” (ROSANO, 2005, p. 274-275- tradução nossa). 
eles um tom paródico, mas não no sentido da revolução política, e sim no de um populismo marginal que diz: tudo bem, na Rosada tem uma puta que veste Dior, e daí? (SARLO, 2005, p. 238).

Talvez as fotografias mais lembradas de Eva Perón sejam mesmo aquelas em vestido de gala que, sendo ou não da Casa Dior, tornavam-se capazes de unir a pompa típica das marchas, que caracterizaram os regimes totalitários, na década de 1940, ao glamour de divas do cinema, como Dorothy Lamour, María Félix e Rita Hayworth. Os braços à mostra e o discreto decote converteram-se no detalhe interessante que, sem ser rigorosamente intencional, mas ao mesmo tempo inevitável,

$[\ldots]$ não atesta obrigatoriamente a
arte do fotógrafo; ele diz apenas ou
que o fotógrafo se encontrava lá, ou,
de maneira mais simplista ainda, que
ele não podia não fotografar o objeto
parcial ao mesmo tempo que o objeto
total (BARTHES, 1984, p. 76).

Esse punctum gracioso vem sendo reproduzido à exaustão nos corpos, fotografias, celuloides e imagens digitais das atrizes que interpretaram Evita na ópera-rock e na grande tela, desde Julie Covington e Elaine Page a Paloma San Basilio e Nacha Guevara; de Madonna a Esther Goris. O famoso exemplar da fotogenia evitista, e da propaganda do populismo peronista, configura um biografema 
que, como a Eva de Copi, em simultâneo combate à morte e em cuidadoso preparativo ao espetáculo no qual se converteria seu enterro, longe está da "miniatura sentimentalista do kitsch, [...] tem a grandiosidade acessivel do melodrama e do camp" (SARLO, 2005, p. 21).

Os trajes de gala e as unhas pintadas precisam de sua utilização "como atributo porque, como se sabe, são uma dimensão fundamental da personagem (teatral e politica)" (SARLO, 2005, p. 21). Os atos de teatralizar, ordenar, articular e isolar-se integram as funções que Barthes (1990) identifica nas espécies de linguas diferenciadas, a seu ver, fundadas nas respectivas escritas de Loyola, Fourier e Sade. A tomar como parâmetro o contexto norte-americano, a cultura homossexual anterior aos protestos de Stonewalll, portanto precursora dos movimentos gays e lésbicos do final dos anos de 1960, também necessitou isolar-se em guetos que, por outro lado, funcionavam como articulação com outros similares entre si em seus desvios à norma e à "normalidade".

Aqui, algumas pessoas, determinados grupos, ordenavam as formas de resistência à repressão, "bien fuera en la literatura y el teatro o sencillamente en la creación y el mantenimiento de espacios de sociabilidad $y$ solidaridad (bares, lugares de encuentro, asociaciones, etc.) (ERIBON, 2000, p. 29) ${ }^{5}$. Além

\footnotetext{
5 “[...] seja na literatura, seja no teatro, ou simplesmente na criação e na manutenção de espaços de sociabilidade e solidariedade (bares, lugares de encontro, associações, etc.)" (ERIBON, 2000, p. 29 - tradução nossa).
} 
de criarem suas gírias e seus jargões nesses locais de socialização, os homossexuais aí formavam e compartilhavam determinados gostos por certas expressões culturais.

O camp, por exemplo, sensibilidade estética da arte popular logo apropriada pela indústria cultural, angariou a predileção dos que adotavam como defesa a sua lógica do cru sarcasmo ou da exagerada crueldade e, como meios de diversão, o excesso, a imitação, a repetição e o travestismo (SONTAG, 2004). Muitas vezes, a própria presença do homossexual no espaço público pronuncia-se sob a forma da "bicha fechativa", excessiva em sua fala e em seu gestual, enquanto shows de dublagens protagonizados por drag queens, transformistas ou travestis fazem-se bastante comuns nos ambientes gays.

Um dos traços camp por excelência, muito presente na homocultura, o arremedo, pode ser observado nos seguintes vestígios da história que, ao mesmo tempo, funcionam como intertextos do universo ficcional de Martínez (2006), nos quais Evita imita ou é imitada: a ópera de Tim Rice e Andrew Lloyd Weber; a canção Don't cry for me Argentina, nas vozes de Sinnead O'Connor e Janice Brown; os filmes dos quais participara Eva Duarte: La pródiga, La cabalgata del circo e El más infeliz del pueblo. Por sua vez, a protagonista do drama de Copi grita para não ser transformada em estátua ou em pintura, enquanto Perón afirma que sua imagem haverá de ser reproduzida ao infinito. 
A repetição própria do camp atinge o musical Evita, constantemente em novas temporadas ao redor do mundo, e as reproduções da figura da protagonista, ornada com a auréola da estátua da Liberdade. Tal característica parece assimilada pelo autor de Santa Evita, quando relaciona uma frase constante nos panfletos que sucederam o atentado ao teatro parisiense, L'Epeé-de-Bois, onde o espetáculo de Copi havia estreado - "Que falta de respeito, que atropelo à boa razão" (p.173) - ao ocorrido com Néstor Perlongher no momento em que, devido à publicação dos três contos de Evita vive, "outros fanáticos invocaram o mesmo tango de [Enrique Santos] Discépolo ao processá-lo por 'atentado ao pudor e profanação': Que falta de respeito, que desplante de maldade insolente" (p. 174, grifos do autor).

O diálogo que o romance em tela empreende com a crítica literária esquadrinha um tipo de referência biografemática na qual ingressam, ao mesmo tempo, um intertexto ficcional - são uma epifania no sentido que Joyce dava à palavra: "uma súbita manifestação espiritual', a alma de um corpo ávido que ressuscita (p. 174) - e outro filosófico: “o que revela é o corpo de uma alma, ou o que Leibniz chamaria de 'o corpo de uma mônada"' (p. 174, grifos do autor). A intertextualidade firmada com as narrativas ficcionais Evita vive e El cadáver de la nación, de Perlongher, destaca a escritura como diferença. Partes desses textos são transcritas para o texto de Martínez, que ainda recontextualiza o "sacrilégio" do sujeito 
produtor ao identificar o primeiro dos textos referidos como paródia de um livro sagrado: o Evangelho segundo São João, capítulo XX, versiculos 14 e 27.

A intertextualidade encadeada, por meio da qual a narrativa em estudo repete de outra forma uma série de obras biográficas, históricas e literárias, substitui a relação autor-texto pela relação leitor-texto: "Alguns dos melhores relatos dos anos 50 são o relato de sua morte" (p. 172). O mesmo pavor que Eva Perón gerou em vida passaria a ser inspirado pelo espetáculo de sua morte que, antecipando os funerais de Judy Garland, outro ícone gay, tornou-se capaz de intimidar as elites "com sua intimidade, exagerada, gritante, a malandra, Evita, a deslavada" (p. 172).

As representações da primeira dama do peronismo, levadas a bom termo por escritores homossexuais, segundo Martínez, contemplam as ambivalências de sua imagem: "Eles a chupam, a ressuscitam, a enterram, enterram fundo nela, a idolatram. São Ela, Ela até a exaustão" (2006, p. 172). Como sabido, o autor-narrador refere-se ao drama de Copi e aos textos nos quais Perlongher demonstra uma vontade de ser Evita,

[...] não se atreve a tocar sua vida e, por isso, toca sua morte: ele apalpa o cadáver, o cobre de joias, o maquia, depila seu buço, desmancha seu coque. Ao contemplá-la de baixo, a endeusa. E como toda Deusa é livre, ele a desenfreia (MARTÍNEZ, 1996, p. 174). 
No entanto, David William Foster (1999) pondera que não fica muito claro como é que o desejo de manter relações sexuais com o corpo de Eva Perón possa ser descrito como um ato gay, embora não deixe de corresponder a uma interpretação cultural válida. O que gera interesse para a homocultura é o encampamento de sua figura, até hoje copiada ad infinitum, por atrizes da grande tela, mulheres na política e travestis dos pequenos shows de prénoitadas, entreatos ou after-hours. O travestimento de Eva faz-se entender não somente por intermédio do uso ostensivo das vestimentas do outro, mas também como qualquer

[...] tipo de vestido o fenómeno parecido que representa estructuras de articulación disidente: adornos del cuerpo, lenguaje corporal, forma de habla afectiva, discurso narrativo y ubicación especial como 'perversiones' de lo putativa e ideológicamente impuesto como 'natural'.

Nesse sentido, a hegemonia apenas tolera os homossexuais e as lésbicas que apresentarem comportamentos discretos. Uma das piores consequências dessa regulação é que, assim, se dispõem a:

\footnotetext{
6 "[...] tipo de vestido ou semelhante fenômeno que representa estruturas de articulação dissidente: enfeites do corpo, linguagem corporal, forma de fala afetiva, discurso narrativo e localização especial como 'perversões' daquilo que é putativa e ideologicamente imposto como 'natural'" (FOSTER, 1999, p. 530-531 - tradução nossa).
} 
[...] reproducir el modelo normativo con el fin de obtener respeto social. El precio implica esconder, entre otros, a los chaperos, a las locas y a las camioneras. El precio es formar pareja estable (o mejor aún: casarse y tener hijos), olvidar el sadomasoquismo, y jamás (jjamás!) hablar de relaciones intergeneracionales. De este modo triunfa una sofisticada tecnología de control social que pretende difundir el modelo heteronormativo entre los y las disidentes ${ }^{7}$.

Até boa parte do século XX, regulações desse tipo atingiam também as mulheres, a julgar pela ausência mais do que sentida, em inúmeras obras biográficas e históricas sobre Eva Perón, da referência ao sexo, que ela mesma queria apagar de sua história particular. De certa forma, os mitos gerados por sua figu$\mathrm{ra}^{8}$ obtiveram tal propósito; silenciando sobre o assunto ou difamando a suposta prostituta, acabaram por sacralizar a sexualidade da personalidade histórica que os tinha origina-

\footnotetext{
7 [...] reproduzir o modelo normativo a fim de obter respeito social. O preço implica esconder, dentre outros, os michês, as bichas-loucas e as camioneiras. o preço é formar união estável (ou melhor ainda: casar-se e ter filhos), esquecer o sadomasoquismo, e jamais (jamais!) falar de relações intergeracionais. Desse modo, triunfa uma sofisticada tecnologia de controle social que pretende difundir o modelo heteronormativo entre os e as dissidentes (ERIBON, 2000, p. 11 - tradução nossa).

8 Segundo o "mito branco", Evita era a virgem em pessoa, a mártir, "síntese e paradigma de todas as mães, a mater doLorosa" (ORTIZ, 1995, p. 338). o "mito negro" obscureceu "essa mulher" com a sombra da ressentida, da prostituta, da "alpinista social", sedenta de poder. Já o "mito vermelho" decorre da apropriação de sua imagem pelos Montoneros, uma das facções guerrilheiras que abrigavam os novos peronistas de esquerda durante os anos de 1970.
} 
do. No conteúdo do romance em análise, para cuja interpretação o sistema referencial tornase auxiliar muito eficaz, uma composição poética não nomeada serve como termo de comparação com a postura de alguns escritores homossexuais em face da imagem de Evita: "Só as bichas-loucas da literatura a inflamam, a desnudam, bolem com ela, como em um poema de Oliverio Girondo" (p. 175).

Entretanto, se a audácia desse poeta opera como precursora da literatura maldita de Perlongher, não é com a diva da indústria ou da comédia musical nem com a drag, tampouco com os ícones da cinematografia camp, tais como Elizabeth Taylor, Joan Crawford e Mae West que a Eva Perón de Copi mais se identifica, e sim com a literatura antiperonista:

En general, una escritura de hombres, que no puede asir el fenómeno del amor odio que despertaba Evita y que revela la imposibilidad de su representación, desde otro punto de vista, que el modo dicotómico del melodrama, por el cual, o es demonizada o canonizada [...] (BURGOS, 2007, p. 68) ${ }^{9}$.

Segundo a análise metatextual de Martínez em Santa Evita, várias escritas ficcionais,

9 Em geral, uma escritura de homens que não pode assegurar o fenômeno do amor ódio que Evita despertava e que revela a impossibilidade de sua representação a partir de um outro ponto de vista que não fosse o modo dicotômico do melodrama pelo qual ou é demonizada ou é canonizada (BURGOS, 2007, p. - tradução nossa). 
baseadas em Evita, prestam-se à estruturação do mito negro e à desestruturação do mito branco, construídos em torno de sua imagem. Então, o que subjaz à ironia de Julio Cortázar, em El examen - "Ela é boa, ela é muito boa, repetem os cabecitas negras que invadem a cidade e acabam transfigurados em fungos e brumas venenosas" (p. 171) - aparece explicitamente no Libro negro de la segunda tiranía, obra anônima: "Aquela estranha mulher era diferente de quase todas as interioranas [...] era veemente, dominadora e espetacular" (p. 171). Ambos os textos citados ligam-se às $\mathrm{Ca}$ tilinárias, de Martínez Estrada: "Devia gostar de fêmeas [...] Ter o descaramento das mulheres públicas na cama, a quem dá na mesma refocilar-se com um habitué de bordel, com uma mascote doméstica ou outra pupila da casa" (p. 171-172).

Esses livros unem-se no repúdio ao "sexo insano" da heroína, vinculando-se à mesma exclusão operada pelas vertentes míticas. O "despudor" de Evita consistiria em infundir, com sua latência erótica, com sua fúria vital, um pavor à sociedade machista em cujos lares as mulheres poderiam converter-se numa ameaça, pois espelhadas naquela que

saía da escuridão da toca e deixava de bordar, engomar as camisas, acender o fogo, preparar o mate, dar banho nas crianças, para se instalar nos palácios do governo e das leis, que eram domínios exclusivos dos homens (p. 171). 
Desse modo, o escritor uruguaio Juan Carlos Onetti e o argentino Jorge Luis Borges, em seus respectivos contos "Ella" e "O simulacro", têm a intenção de esconjurar o fantasma da esposa de Perón, evidenciando a barbárie que representava seu culto, prestado pelos "negros" das provincias e pelos pobres dos subúrbios. Porém Martínez infere que, sem querer, Borges homenageia a imensidão da protagonista porque, no conto "O Simulacro", "Evita é a imagem de Deus mulher, a Deus de todas as mulheres, a Homem de todos os deuses" (p. 172). Daí que a literatura, restrita ao corpo morto e ao sexo insano da heroína em escrituras masculinas, assim resulte ampliada, embora a contragosto.

Não é apenas no desejo capaz de deslocar ou realocar as significações do feminino e do masculino, da vida e da morte, que reside a importância das obras de Copi e Perlongher, sobre as quais Adrián Melo, em El amor de los muchachos: homosexualidad y literatura, afirma:

[...] parecen asimilar, apropiarse y reinterpretar diversos simbolos y elementos a partir de los cuales se ha construido el mito de Evita: la radio y el cine, la cabellera rubia, el rodete, las joyas y los sombreros, las máquinas de coser, las frazadas, la demagogia $y$ el autoritarismo, las armas compradas al principe de Holanda para armar a la clase trabajadora, la simulación y el travestismo (Martinez Estrada y Borges dirian que Eva era un macho), el cáncer, los funerales como espectáculo melodramático, el esmalte Revlon de las uñas del cadáver, la necesidad de 
derramar la propia sangre para entrar en la historia argentina, la instrumentación politica de la muerte, el maquillaje, el auténtico dolor de miles de humildes que sintieron que sus vidas no volverian a ser las mismas con la ausencia de ella ${ }^{10}$.

O sucesso de público, angariado pelas produções melodramáticas que ganham veiculação pelas distintas formas da cultura de massa latino-americana, parece responder ao enraizamento de alguns dos seus elementos, tais como a pobreza e a riqueza, o bem contra o mal, no imaginário coletivo. Sendo o melodrama uma forma vital de imaginação e uma prática relacionada à modernidade, em que sobressaem a dimensão simbólica, a emocionalidade e o gestual, como infere Peter Brooks (1976), o seu êxito na Argentina, onde impregnou a radionovela, o radioteatro e o cinema dos anos 1930/1940, não se descura de uma nova realidade sociocultural proporcionada pelo populismo peronista.

10 "[...] parecem assimilar, apropriar-se e reinterpretar diversos símbolos e elementos a partir dos quais se construiu o mito de Evita: o rádio e o cinema, a cabeleira loura, o coque, as joias e os chapéus, as máquinas de costura, os cobertores, a demagogia e o autoritarismo, as armas compradas ao príncipe da Holanda para armar a classe trabalhadora, a simulação e o travestismo (Martínez Estrada e Borges diriam que Eva era um macho), o câncer, os funerais como espetáculo melodramático, o esmalte Revlon das unhas do cadáver, a necessidade de derramar o próprio sangue para entrar na história argentina, a instrumentação política da morte, a maquiagem, a autêntica dor de milhares de humildes que sentiram que suas vidas não voltariam a ser as mesmas depois da ausência dela” (MELO, 2005, p. 240 - tradução nossa). 
Desse modo, ao redor de Eva Perón, montava-se uma particular forma de hibridismo cultural em que:

[...] las lógicas de representación del Estado se tiñeron con las de la industria cultural y adquirieron el formato melodramático. El cuerpo, vivo y muerto, de Eva traspasó los mecanismos peronistas de control, superó ese efecto de 'balcón' al que se refiere Jon Beasley-Murray como el limite necesario que el populismo impone a las masas. Sólo ella fue capaz de entremezclarse con la multitud, y ganarse asi en el imaginario popular un lugar de leyenda ${ }^{11}$.

De acordo com Adrián Melo (2005, p. 238), não podemos compreender Evita, sua linguagem e sua oratória, se não levarmos em conta seu passado no radioteatro e na cinematografia argentina. Sua vida apresenta uma série daqueles sentimentos que garantiam a exitosa recepção do folhetim popular: a pobreza, o abandono, a queda, a vingança, a redenção. O melodrama vivido por ela se concluiria de forma camp, com a exposição pública de sua agonia em meetings do regime e nas inúmeras

11 "[...] as lógicas de representação do Estado tingiram-se com as da indústria cultural e adquiriram o formato melodramático. o corpo, vivo e morto, de Eva ultrapassou os mecanismos peronistas de controle, superou esse efeito de 'sacada' ao qual se refere Jon Beasley-Murray como o limite necessário que o populismo impõe às massas. Somente ela foi capaz de se entremesclar com a multidão, e assim conquistar, no imaginário popular, um lugar de lenda” (ROSANO, 2005, p. 19 - tradução nossa). 
reproduções que, junto a demonstrações de dó e piedade, multiplicavam-se por entre fotos e vídeos da recente televisão nacional.

Como mediadora entre o povo e os discursos da ordem peronista, Eva se valeu de sua experiência com o melodrama, talvez mais como receptora do que como intérprete, por exemplo, de famosas heroínas da história universal, tais como Ana da Áustria, Catarina, a Grande e Madame Lynch. Assim, não se mostraria desprezivel, segundo avalia Alejandro Susti González (2007), a reutilização de dispositivos de sedução própria das notações culturais populares, como o suspense, a estrutura aberta do texto, a confusão relato-vida, realidade-ficção, responsáveis por criar maior intimidade com os destinatários, sobretudo dos discursos públicos e radiofônicos, bem como da propaganda oficial impressa e radiotransmitida.

Para Susti (2007), o grande trunfo de Eva Perón, conquistado a partir do contato que travou com o imaginário produzido pela cultura popular de massas, consiste em ter sido modelo de uma trajetória à qual todo homem e, então, toda mulher das classes médias e populares podiam aspirar, desde o momento em que seu ingresso numa modernidade pelo menos periférica (SARLO, 1988) havia sido facilitado pelos mass media, especialmente pela publicidade, já nas décadas anteriores ao peronismo. No julgamento de David William Foster, o atrativo básico daquela líder carismática 
[...] ha sido el de la mujer fuerte, capaz de aumentar el poder que le permite desafiar a la sociedad machista, adoptando a menundo los signos exteriores mismos del poder del macho. Aún así, la mujer no se convierte en macho, sino que lo desplaza a través del gesto deconstructivo de una presencia cuidadosamente elaborada que pone en tela de juicio la 'la naturalidad' de la pose masculinista, y al mismo tiempo señala cómo el poder y la presencia son construcciones complejas que conllevan comportamientos igualmente complejos ${ }^{12}$.

A complexidade abarcada por Eva Perón (como primeira-dama e militante política, como pobre e logo rica, como a garota que queria ser atriz ao estilo de Norma Shearer e a benfeitora social de atuação recriminada ou louvada) resulta de uma autoinvenção que muito deve ao seu aprendizado com as textualidades da cultura de massa, principalmente daquela que, saída do campo, há pouco se instaurava nos centros urbanos ou às suas margens. Esse processo pouco tem a ver com a "cidade letrada" de Borges, Cortázar, Martínez-Estrada e Onetti, mas guarda algum débito para com o gênero textual do conto de fadas, de algum

12 "[...] foi o da mulher forte, capaz de aumentar o poder que the permite desafiar a sociedade machista, adotando com frequência os mesmos signos exteriores do poder do macho. Mesmo assim, a mulher não se converte em macho, mas o desloca através do gesto desconstrutivo de uma presença cuidadosamente elaborada que põe em questão 'a naturalidade' da pose masculinista e, ao mesmo tempo, assinala como o poder e a presença são construções complexas que implicam comportamentos igualmente complexos” (FOSTER, 1999, p. 530 - tradução nossa). 
modo, presente no imaginário popular, ainda que nunca lido em texto escrito:

Cada um lê o mito do corpo como quer, lê o corpo de Evita com as declinações de seu olhar. Ela pode ser tudo. Na Argentina ela ainda é a Cinderela das telenovelas, a nostalgia de ter sido o que nunca fomos, a mulher justiceira, a mãe celestial (p. 176).

\footnotetext{
Convém recordar, com Foster (1999, p. 530), que
}

El cuento de la Cenicienta respecto a alguien como Evita es homólogo al programa de construcción personal - el cuerpo y la identidad sexual como trabajo progresivo - que es tan importante para la sensibilidad gay ${ }^{13}$.

Não menos importante é a figura da mulher poderosa que, relacionada à protagonista de Santa Evita, remete à literatura infantojuvenil, aqui mediada pela interpretação psicanalítica. Essa outra forma de biografema homocultural apresenta-se no discurso do coronel Moore Koening, responsável pela guarda do cadáver embalsamado de Eva, o qual projeta nela a figura masculina do sedutor perigoso (Cf. BETTELMEIM, 1980, p. 201) que se

\footnotetext{
13 "A história da Cinderela transposta a alguém como Evita torna-se homóloga ao programa de construção pessoal - o corpo e a identidade sexual como trabalho progressivo - que é tão importante para a sensibilidade gay” (FOSTER, 1999, p. 530 - tradução nossa).
} 
transforma, caso o permitam, em destruidor da bondade nos contos de fadas:

Uma criada com pretensões a rainha. Agressiva, nada feminina. Coberta de joias da cabeça aos pés para se desforrar das humilhações que viveu. Ressentida. Inescrupulosa. Uma vergonha (p. 117).

Outra personagem de certa constância nos contos maravilhosos, o caçador empresta a presença responsável e salvadora, associada a sua figura, a fim de revelar as propensões altruístas e protetoras que os descamisados argentinos atribuem a sua benfeitora:

Sabia que, depois de sua morte, as cartas pedindo vestidos de noiva, móveis, empregos, brinquedos, o diabo a quatro, deviam ir em seu nome para obterem resposta (p. 117).

Morta, Evita retira seu poder dos dois principais mitos erigidos em torno de sua breve existência, pois na literatura, do mesmo modo que nos contos de fadas, a morte prematura do herói “- à diferença da morte de uma pessoa idosa, depois de ter vivido - simboliza o fracasso" (BETTELHEIM, 1980, p. 216) do ser humano frente ao tempo.

Trata-se menos de especular quanto poder teria se viva fosse, e mais de desvendar os significados de sua postura no contexto hipermasculinista e homofóbico da Argentina dos anos de 1940 e 1950, segundo David William 
Foster (1999, p. 531), para quem,

La alianza entre la Evita histórica e iconográfica y el movimiento gay - y aún queda por determinar si Evita es una imagen potente para un segmento de los gays masculinos para quienes la mujer poderosa tiene significado o para las lesbianas que pueden apreciar su reto al privilegio masculinista - es también una cuestión de proyecciones interpretativas ${ }^{14}$.

Em diversas narrativas históricas e versões ficcionalizadas que tentam interpretar sua vida, ela teria ajudado a dar à luz uma nova Argentina, sem a consumação do ato sexual (como a Virgem Maria). O passado de humilhações evocado por seus detratores, tal e qual o beijo ao sapo nos contos de fadas, revela-se como a busca de uma identidade que, antes de pessoal, é social. Desvelada na ficção biográfica, Eva Perón encarna "a nostalgia de ter sido o que nunca fomos, a mulher justiceira, a mãe celestial. Fora do país, é o poder, a morta jovem, a hiena compassiva declamando nos balcões do além: 'Não chores por mim, Argentina" (p. 176).

No Condado do Sexo Médio (ou do MeioSexo, ou do Sexo Medíocre), subúrbio norte

\footnotetext{
14 "A aliança entre a Evita histórica e iconográfica e o movimento gay - e ainda falta determinar se Evita é uma imagem potente para um segmento dos gays masculinos para o qual a mulher poderosa encontra significado ou para as lésbicas que podem apreciar sua provocação ao privilégio masculinista é também uma questão de projeções interpretativas" (FOSTER, 1999, p. 531 - tradução nossa).
} 
-americano onde Martínez escreveu o romance em estudo, Evita é "tão familiar como a estátua da Liberdade, com a qual, de quebra, ela se parece" (p. 176). Na voz de Sinnead O'Connor, cantora cuja cabeça raspada exprime um visual andrógino e cujas verbalizações marcaram-se por protestos às politicas do centro euro-americano de poder, Tomás Eloy Martínez reconhece a voz de Eva Perón: ambas, com "erres arrastados e ruminantes, pronunciam 'Arghentina' como se o gê fosse um erre da minha provincia natal" (p. 176). Em New Jersey, "ninguém sabe quem foi a Evita da realidade; a ópera de Tim Rice a popularizou, embora muitos americanos possam imaginar que a Argentina seja um subúrbio de Guatemala City" (p. 176).

Contra essa visão de um centro hegemônico, e com o fogo no qual Eva deixou seu nome, o autor escreveu o nome de seu distante país, visto de fora, mas também de dentro, e das margens, ainda que desde um centro, onde ia "avançando, dia após dia, pelo frágil fio entre o mítico e o verdadeiro, deslizando entre as luzes do que não foi e as sombras do que poderia ter sido. Vou perdendo-me nesses meandros e Ela sempre me encontra" (p.177). Mesmo ao fornecer biografemas do ícone camp, da heroína melodramática e da mulher poderosa na espécie de critica metatextual a que procede em seu romance, Martínez recorre ao imaginário cristão ocidental, às narrativas sólidas da teoria literária, da filosofia, do mito e da própria literatura canônica. 
Apesar da extrema boa vontade em sua abordagem às damas de papel reconstruídas pela escritura gay argentina, talvez resultante do manejo da epistemologia contemporânea, em especial da estética pós-modernista, devido a sua atuação como professor, em universidades norte-americanas, falta-lhe o corpo-acorpo com a homocultura para empreender análises mais amplas das vinculações entre a figura de Evita, a dicção ficcional homoerótica e as expressões homoculturais. Por tal razão, necessitamos aqui suplementar, com apoio em estudiosos do tema, as perspectivas do autor que ora revisamos, pois da mesma forma que Eva Perón, na breve vida por ela vivida, expôs com exagero seus luxos, "uma fantasia, um jogo burguês, nada mais, as regras do cerimonial" (RICE, 1997, p. 18), como canta a protagonista da ópera de Andre Lloyd Weber e Tim Rice, "el sujeto sexual marginado puede juzgar necesario o ventajoso exagerar la diferencia, disidencia y desviación, lo cual es, en gran parte, el poder significante de la screaming queen“ (FOSTER, 1999, p. 531) ${ }^{15}$.

Os mesmos desafios à norma e ao normatizado evidenciam-se nas conhecidas irritações e pirraças de Evita, em "sus lapsus estratégicos con lenguaje de bar y prostíbulo, su negativa a adherirse al protocolo consagrado"16. Esses traços

15 "[...] o sujeito sexual marginalizado pode julgar necessário ou vantajoso exagerar a diferença, dissidência e desviação que é, em grande parte, o poder significante da screaming queen [a bichinha cheguei]" (FOSTER, 1999, p. 531- tradução nossa).

16 “[...] seus lapsos estratégicos com linguagem de bar e pros- 
aparecem na dessacralização da mulher realizada pelas protagonistas de Perlongher, mas não pela de Copi, que até mesmo ao lhe dar um poder maior que o de Perón, retroage a uma época que não é a sua. Parecendo desconhecer os novos ares trazidos pelo maio de 1968, e a militância GL do mesmo período, o autor recupera o imaginário e o vocabulário da caserna e do clero contemporâneos ao golpe que derrubou Perón, a ironicamente denominada "revolução libertadora".

Por seu turno, as personagens de Evita vive (1975), El cadáver (1980), Joyas macabras (1983) e El cadáver de la nación (1989), elaboradas entre os anos mais sangrentos do autoritário Processo de Reorganización Nacional e a reestruturação pós-ditatorial, fazem notar a passagem do tempo numa espécie bem platina de nostalgia, a enxergar no "isso foi" do nascente movimento gay argentino uma esperançosa ligação entre homossexualidade e politica que agora se esvai em meio "ao isso nunca mais será o mesmo", no qual ressaltam a cooptação das subjetividades desviantes, o aliancismo partidário, a heteronormatividade dos meios de comunicação e os apelos do mercado de consumo. Não era mesmo aos casais homotelevisivos chancelados pela grande midia globalizante, mas aos "viados" de todos os paraísos perdidos que Martínez assim se referia: "Elas a possuem, a apalpam, se entregam a ela. Mas afinal de contas, não foi isso que Evita pediu que o povo fizesse com sua memória?” (p. 175).

tíbulo, sua negativa de aderência ao protocolo consagrado" (FOSTER, 1999, p. 531 - tradução nossa). 


\section{REFERÊNCIAS}

ARFUCH, Leonor. O espaço biográfico: dilemas da subjetividade contemporânea. Tradução de Paloma Vidal. Rio de Janeiro: EdUERJ, 2010.

BARTHES, Roland. Câmara clara. Tradução de Júlio Castañon Guimarães. Rio de Janeiro: Nova Fronteira, 1984.

- Sade, Fourier, Loyola. Tradução de Mário Laranjeira. São Paulo: Brasiliense, 1990. BETTELHEIM, B. A psicanálise dos contos de fadas. Tradução de Arlene Caetano. Rio de Janeiro: Paz e Terra, 1980.

BROOKS, Peter. The melodramatic imagination: Balzac, Henry James, melodrama and the mode of excess. London: Yale University Press, 1976. (With a new preface).

BURGOS, Nidia. Los textos literarios sobre Eva Perón. Apropiaciones, representaciones y desplazamientos del imaginario popular. Imaginario, São Paulo, v. 13, n. 14, p. 1, jun. 2007. Disponivel em: <http://pepsic.bvsalud. org/scielo.php?script=sci_arttext\&pid=S1413$666 \times 2007000100005 \& 1 \mathrm{ng}=\mathrm{pt} \& \mathrm{nr} \mathrm{m}=$ iso $>$. Acesso em: 26 dez. 2013.

DOSSE, François. La apuesta biográfica: escribir una vida. Valencia: EdUV, 2007. 
ERIBON, Didier. Identidades: reflexiones sobre la cuestión gay. Tradução de José Miguel Marcén. Barcelona: Bellaterra, 2000.

FOSTER, David William. Evita, Juan José Sebreli y género. Revista Canadiense de Estudios Hispánicos (RCEH), Edmond, ..., ..., ..., v. 23, n. 3, p. 529-537, Spring; 23 mar. 1999.

GOLDAR, Ernesto. E1 peronismo en la literatura argentina. Buenos Aires: Freeland, 1971.

JAUMANDREU, Paco. La cabeza contra el sue1o: memorias. Buenos Aires: Corregidor, 1981.

. Evita fuera del balcón. Buenos Aires: Ediciones del Libro Abierto, 1981.

LAMBORGHINI, Osvaldo. El fiord. Buenos Aires: Chinatown, 1969.

MARTÍnEZ, Tomás Eloy. Santa Evita. Buenos Aires: Planeta, 1995.

MARTÍNEZ, Tomás Eloy. Santa Evita. Tradução de Sergio Molina. São Paulo: Companhia das Letras, 1996.

MELO, Adrián. E1 amor de los muchachos: homosexualidad \& literatura. Buenos Aires: Lea, 2005.

ORTIZ, Alicia Dujovne. Eva Perón: la biografia. Buenos Aires: Aguilar, 1995. 
PERLONGHER, Néstor. Evita vive (1975). E1 cadáver (1980). Joyas macabras (1983). El cadáver de la nación (1989). In: PERLONGHER, Néstor. Prosa plebeya. Buenos Aires: Colihue, 2008. (Selección y prólogo de Christian Ferrer y Osvaldo Balgorria).

PUIG, Manuel. La tajada. In: AMÍCOLA, José (Ed.). Materiales iniciales para 'La traición de Rita Hayworth'. La Plata: Centro de Estudios de Teoría y Crítica Literaria: Universidad Nacional de La Plata, 1966.

RICE, Tim. Don't cry for me Argentina.

In:_ Evita (Songbook). [London?]: Hal

Leonard, p1997. 1 CD (ca. 60 min), faixa 18.

ROSANO, Susana. Rostros y máscaras de Eva Perón: imaginario populista y representación (Argentina, 1951-2003). 2012. Tese (Doutorado em Filosofia) - University of Pittsburgh, Pittsburg, 2005.

SARLO, Beatriz. Una modernidad periférica. Buenos Aires, 1920-1930. Buenos Aires: Nueva Visión, 1988.

SARLO, Beatriz. A paixão e a exceção: Borges, Eva Perón, Montoneros. São Paulo: Companhia das Letras; Belo Horizonte: EdUFMG, 2005. SEBRELI, Juan José. Eva Perón, ¿aventurera o militante? Buenos Aires: Editorial Siglo XX, 1966. 
SONTAG, Susan. Camp - algumas notas. In: Contra a interpretação e outros ensaios. Lisboa: Gótica, 2004.

SOUZA, Eneida Maria de. Crítica cult. Belo Horizonte: EdUFMG, 2002.

SUSTI GONZÁLEZ, Alejandro. "Seré millones": Eva Perón: melodrama, cuerpo y simulacro. Rosario: Beatriz Viterbo Editora, 2007.

TABORDA, Raúl Natali Roque Damonte Botana (Copi). Eva Perón. Tradução de Jorge de Monteleone. Buenos Aires: Adriana Hidalgo, 2000.

WALSH, María Elena. Eva. In: . Canciones contra el mal de ojo. Buenos Aires: Sudamericana, 1976. 